\title{
FNANBIA
}

BOUTSRAPPING

AMONG

BOSIA RIBAN

SMALL

BUSTNESSES:

AN EXPLORATORYY

STUDY

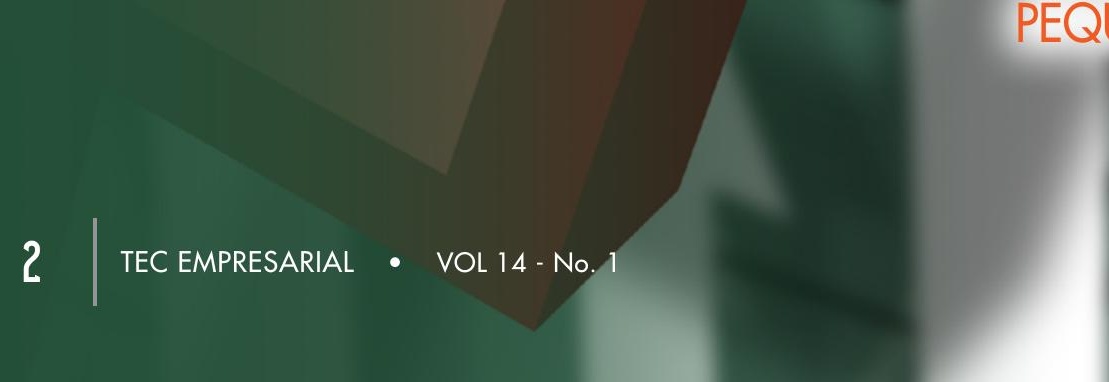

BOOTSTRAPPING FINANCIERO EN LA PEQUEÑA EMPRESA COSTARRICENSE: 
This study identifies and analyzes the financial bootstrapping techniques commonly used by small businesses in Costa Rica. The empirical application uses a unique sample of 161 Costa Rican SMEs for 2017. The results of the parallel factor analysis reveal that the analyzed SMEs adopt different types of bootstrapping techniques primarily related to the owners, customers, and alliances that facilitate the joint utilization of facilities and other assets. Entrepreneurs bootstrap their businesses to reduce the reliance on external financing. In this sense, the results of this study show that, rather than simply using what entrepreneurs are familiar with (e.g., credit from family or friends), Costa Rican small business managers are exploring and actively using a wide array of alternative methods in order to access financial resources.

KEYWORDS: Financial bootstrapping, small business finance, Costa Rica

\section{Marco Alvarado}

Director, Department of Academic

Programs, Universidad Latinoamericana de Ciencia y Tecnología. PhD candidate Escuela de Administración de Empresas del Instituto Tecnológico de Costa Rica. malvaradom@ulacit.ac.cr 'financial bootstrapping' comúnmente utilizadas por las empresas en Costa Rica. La aplicación empírica utiliza una base de datos única que incluye información de 161 pequeñas y medianas empresas (pymes) costarricenses para 2017. Los resultados del análisis de factores paralelos revelan que las pymes analizadas adoptan diferentes tipos de técnicas de 'financial bootstrapping' principalmente asociadas a los propietarios, clientes y alianzas que facilitan la utilización conjunta de las instalaciones y otros activos. Los empresarios emplean técnicas de 'financial bootstrapping' en sus negocios para reducir la dependencia del financiamiento externo. En este sentido, los resultados de este estudio muestran que, en lugar de simplemente usar métodos que son familiares a los empresarios (por ejemplo, crédito de familiares o amigos), los gerentes de la pequeña empresa en Costa Rica están explorando y activamente utilizando una amplia gama de métodos alternativos para acceder a recursos financieros.

\section{Ronald Mora-Esquivel}

Professor. Escuela de Administración de Empresas del Instituto Tecnológico de Costa Rica, Costa Rica. rmora@itcr.ac.cr 


\section{INTRODUCTION}

\section{T}

his study deals with the identification and analysis of the financial bootstrapping techniques commonly used by small businesses in Costa Rica. The relevance of this work flows from the recognition that, along with the relevance of small and mediumsized enterprises (SMEs) to the economy in terms of job creation or increased economic output and progress (e.g., Aghion, 2017; Lafuente et al., 2019), SMEs face important resource constrains that limit or condition their survival and growth (e.g., Cooper et al., 1994; Storey, 1994; Davila et al., 2003). In this sense, access to financial resources is a critical objective for SMEs and the understanding of how small businesses respond to financial constraints is crucial to offer solutions rooted in entrepreneurship research as well as to advance the prescriptive literature on small business financing.

Because of the difficulties in raising finance from traditional economic agents-i.e., financial institutions or equity markets-that primarily result from information asymmetries problems (Harrison et al., 2004), SMEs increasingly adopt financial bootstrapping practices to respond to these constraints (Ebben and Johnson, 2006; Grichnik et al., 2014; Horváth and Szerb, 2018).

Financial bootstrapping-a term first coined by Bhide (1992)-refers to the set of potentially creative practices available to entrepreneurs that help reducing operating costs and improving cash flow management. Therefore, entrepreneurs bootstrap their businesses in order to reduce the reliance on external financing (Winborg and Landström, 2001).

Academic research has primarily analyzed and catalogued financial bootstrapping practices used by SMEs in developed contexts (e.g., Harrison et al., 2004; Ebben and Johnson, 2006; Vanacker et al., 2011; Grichnik et al., 2014). On contrary, the specific analysis of how SMEs adopt bootstrapping techniques in developing economies has been largely sidelined in prior work (in this sense, the work by Horváth and Szerb (2018) is a welcome exception). This is the focus of this study. More concretely, we analyze the extent to which Costa Rican SMEs use different financial bootstrapping techniques.
Similar to Horváth and Szerb (2018), the proposed analysis helps to profile businesses in terms of the adopted bootstrapping techniques. Also, the implementation of bootstrapping techniques has been linked to strategic choices designed to optimize the use of internal resources and the business' cost structure (Aldrich \& Auster, 1986; Hudson et al., 2001), and this study contributes to unveil organizational trajectories based on the underlying properties of bootstrapping techniques that might favor their joint implementation in often dissimilar businesses.

The empirical application uses a unique dataset that includes information for 161 Costa Rican SMEs surveyed in 2017. By employing a parallel factor approach (Hayton et al., 2004), the proposed analysis allows both to catalogue 19 financial bootstrapping techniques commonly identified in the literature, and to unveil the intensity with which Costa Rican SMEs implement these cash management practices.

The remainder of the study is structured as follows. Section 2 presents the literature review. In Section 3, the data and the method are described. The results are shown in Section 4. Finally, in Section 5 we present the concluding remarks and future research lines.

\section{LITERATURE REVIEW: FINANCIAL BOOTSTRAPPNNG TECHNIQUES}

Building on prior work on small business financing, financial bootstrapping is defined as the set of methods or practices used by businesses to optimize cash management by reducing operating costs and improving cash flow management (Carter and Van Auken, 2005; Ebben and Johnson, 2006; Grichnik et al., 2014; Horváth and Szerb, 2018). Winborg and Landström (2001) conclude that financial bootstrapping techniques are commonly used by SMEs, regardless of their market experience. According to these authors, bootstrapping enables 'meeting the need for resources without relying on long-term external finance from debt holders and/or new owners' (Winborg and Landström, 2001, pp. 235-236). 
Prior literature underlines that financial bootstrapping are resourceful managerial practices that contribute to optimize resource exploitation within the business and reduce the overall cost and risk of operations, while avoiding reliance on external suppliers of finance (Winborg and Landström, 2001; Ebben and Johnson, 2006; Winborg, 2009). Furthermore, Venkataraman (2003) suggests that bootstrapping offers an ideal strategic pathway to escape the vicious cycle of resource constraints.

Following this intuition, as businesses engage in bootstrapping to structure, bundle, and leverage their resource base, they overcome financial constraints and market dependencies and introduce new managerial frameworks that give the business high degrees of freedom and superior self-financing organization (Vanacker et al., 2011).

Previous research on financial bootstrapping has mostly focused on cataloguing bootstrapping techniques and examining the connection between bootstrapping techniques and performance.

Concerning the first research line interested in cataloguing bootstrapping techniques, past studies have sought to classify bootstrapping practices following two approaches. The first group uses the classification by Freear et al. (1995) who distinguish bootstrapping techniques related to business development (e.g., leasing equipment instead of purchasing) from product development techniques (e.g., research and development funded by the customer).

The second group was proposed by Winborg and Landström (2001) who classified bootstrapping practices in six groups: (1) owner-related practices (e.g., withholding manager's salary), (2) minimization of accounts receivable (e.g., conditions offered to customers), (3) joint utilization (e.g., borrowing equipment from other businesses), (4) delaying payments (e.g., delaying payment to suppliers), (5) minimization of stocks (e.g., using routines in order to minimize stocks), and (6) public subsidies.

In the case of the second stream (analysis of the relationship between bootstrapping techniques and performance), it should be noted that existing work

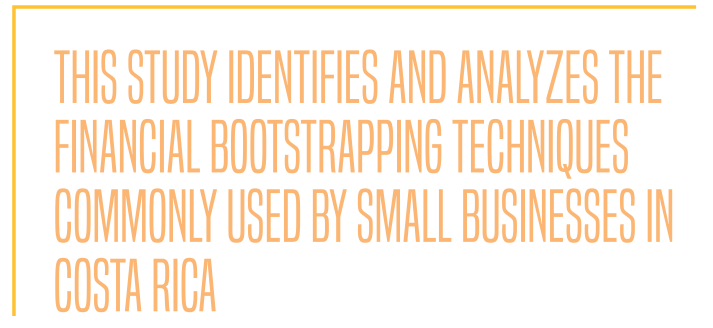

has mostly adopted the latter classification to analyze the influence of bootstrapping techniques on business performance metrics (see e.g., Ekanem, 2005; Ebben and Johnson, 2006; Grichnik et al., 2014). Although prior studies highlight the positive effects of financial bootstrapping, the sign and intensity of the connection between performance variations and bootstrapping techniques is heterogeneous and sometimes controversial. For example, Jones and Jayawarna (2010) indicated that a positive relationship exists between sales growth and payment-related and joint-utilization methods. On contrary, Ebben (2009) found a negative relationship between performance ratios (ROS and ROA) and the joint utilization of resources, payment delays, and customerrelated techniques, while owner-related methods were found to positively influence liquidity ratios.

The study by Patel et al. (2011) concluded that bootstrapping techniques have an inverse U-shaped relationship with venture growth; and that a strategy combining strategic alliances with bootstrapping techniques is conducive to employment growth and mitigates the downward effect of excessive bootstrapping use. Vanacker et al. (2011) reported a positive effect on value added of techniques related to the use of owners' own funds, the hiring of interim personnel, government subsidies, and the minimization of accounts receivable. Nevertheless, these authors found that informal investments from family or friends, running the business from home, sharing premises, joint purchases, delaying payments, and minimizing investments negatively impact value added.

In their study of Hungarian SMEs, Horváth and Szerb (2018) found that the use of digital and IT-based bootstrapping practices yields superior performance among businesses with a low knowledge-based 
competitive advantage, that is, firms that do not operate in knowledge intensive service activities (KISA) sectors. The authors also found that the characteristics of KISA firms-e.g., high knowledge exploitation, high use of ITs in business operations, and high customization and strong interaction with consumers-are more compatible with customer-oriented business models, which may explain the positive relationship between customer-oriented bootstrapping practices and performance in KISA firms.

\section{DATA AND METHOD}

\section{DATA}

The data used in this study comes from a unique dataset of Costa Rican SMEs for the year 2017. As part of a research project, the questionnaire employed in this work was designed specifically for the purposes of this study by a research team at the Costa Rica Institute of Technology (ITCR). Entrepreneurs are the potential respondents, and they were approached face-to-face with a request to participate in the study. Participants received confirmation on confidentiality and the research team leading the investigation offered feedback on the survey results to the businesses in order to encourage participation. Data collection was achieved through self-administrated, structured interviews, where the entrepreneur or the manager was asked to answer essentially closed questions. The questionnaire for the survey was applied by a team of the ITCR. It should be kept in mind that, following the practice recommended in the literature (Colton and Covert, 2007), the questionnaire was subject to a pre-test in order to correct potentially ambiguous or confusing questions.

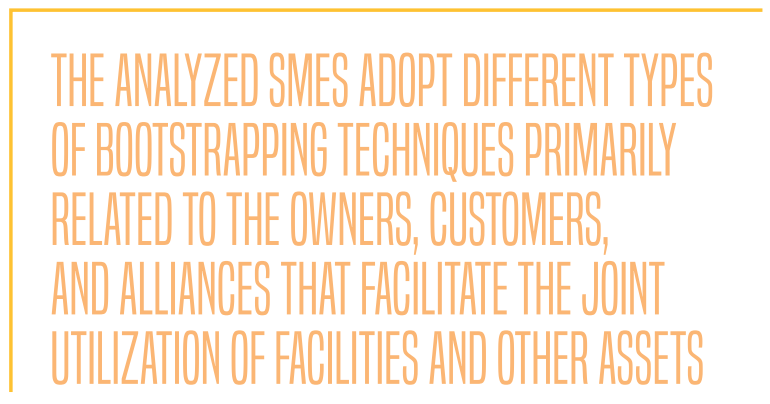

The information was collected between June and August 2017. In a first stage, a total number of 530 owners of SMEs operating in manufacturing, trade and technology-based service sectors in Costa Rica were invited to participate in the study. The final sample used in this study comprises information for 161 Costa Rican entrepreneurial businesses.

\section{BOOTSTRAPPING TECHNIQUES AND METHOD}

In this study, we carried out a factor analysis to verify if the set of analyzed variables are connected to different bootstrapping strategies previously identified in the literature. In this sense, entrepreneurs were asked if they have used in the last three years a series of items identified from the literature as relevant financial bootstrapping techniques $(0=$ not used and $1=$ used). From our questionnaire it is possible to obtain information for 24 financial bootstrapping techniques. We carried out an exploratory factor analysis to evaluate how well the observed independent variables reflect unobserved (latent) variables according to the proposed structure.

Because the analyzed variables are dichotomous, we employed the parallel factor approach (Hayton et al., 2004) based on a polychoric matrix to estimate factor loadings (the type of rotation chosen was VARIMAX). The items that could not improve the reliability (Cronbach's alpha) of its corresponding factor were dropped from the analysis (Lafuente et al., 2010). This procedure reduced the number of bootstrapping techniques included from 24 to 19. The software Factor 10.9.02 was used to compute the factor analysis (Ferrando and Lorenzo-Seva, 2017).

The final list of 19 dichotomous items analyzed in this study includes practices commonly used in previous studies dealing with the analysis of financial bootstrapping techniques (e.g., Winborg and Landström, 2001; Carter and Van Auken, 2005; Ebben and Johnson, 2006; Winborg, 2009; Grichnik et al., 2014; Horváth and Szerb, 2018). Descriptive statistics for the bootstrapping techniques included in the factor analysis are presented in Table 1. 
RESULTS

This section deals with the findings of the empirical analysis. The outcome of the parallel factor analysis is presented in Table 2.

From Table 2 we find that the 19 observed bootstrapping techniques can be grouped into three latent factors which have been classified as follows: (1) financingrelated techniques (factor 1), (2) customer-related and resource optimization (factor 2), and (3) joint utilization (factor 3).
Concerning the goodness-of-fit statistics, the result of the Bartlett's test of sphericity (value $=544.20$ and $p$-value < 0.00oo) confirms that the correlation between the analyzed variables does not contaminate the findings of the parallel factor analysis. Also, the result of the Kaiser-Meyer-Olkin (KMO) index of sampling adequacy is above the recommended cut-off point of 0.50 (0.7087), corroborating that the sample is factorable.

The results of the reliability test (Cronbach's alpha) for the three factors obtained ranges between 0.6295 and o.6340 (Table 2), confirming that the constructs extracted

Table 1. Descriptive statistics for the variables considered in the analysis

\begin{tabular}{|c|c|c|c|}
\hline & Financial bootstrapping technique & Mean & Std. Dev. \\
\hline 1 & Use of entrepreneur's credit card for business expense & 0.432 & 0.495 \\
\hline 2 & Commercial loan from family / friends & 0.327 & 0.469 \\
\hline 3 & Withholding managers' salary & 0.191 & 0.394 \\
\hline 4 & Employ relatives or friends at below-market salary & 0.309 & 0.462 \\
\hline 5 & Cease business relations with late payers & 0.407 & 0.491 \\
\hline 6 & Use methods that speed-up invoicing & 0.228 & 0.420 \\
\hline 7 & Use of interest rate on overdue payments & 0.130 & 0.336 \\
\hline 8 & Offer same conditions (price, commercial credit, etc.) to all customers & 0.420 & 0.494 \\
\hline 9 & Borrow equipment from other businesses & 0.160 & 0.367 \\
\hline 10 & Coordinate purchases (suppliers) with other businesses & 0.235 & 0.424 \\
\hline 11 & Use bartering (instead of buying) for goods and services (inputs) & 0.235 & 0.424 \\
\hline 12 & Lease equipment instead of buying & 0.216 & 0.411 \\
\hline 13 & Delay payment to suppliers & 0.210 & 0.407 \\
\hline 14 & Use routines in order to minimize stocks & 0.377 & 0.485 \\
\hline 15 & Use discounts for customers that pay in cash & 0.420 & 0.494 \\
\hline 16 & Raise capital from a factoring business & 0.074 & 0.263 \\
\hline 17 & Choose customers who pay quickly & 0.469 & 0.499 \\
\hline 18 & Share premises / facilities with other businesses & 0.216 & 0.411 \\
\hline 19 & Share employees with other businesses & 0.185 & 0.389 \\
\hline
\end{tabular}

Note: Number of observations $=161$ businesses 
from the parallel factor analysis are internally consistent across items to measure the underlying categories under evaluation. Overall, these findings confirm that our approach to factor analysis is robust and appropriate (Nunnally \& Bernstein, 1994).

The proposed parallel factor analysis explains $47.32 \%$ of the total variance, and the latent constructs identified appear consistent with previous studies on financial bootstrapping techniques.

Building on the categorization by Winborg and
Landström (2001), the first factor includes eight techniques connected to owner-related practices and delaying payment techniques. This factor identified as 'financing-related' bootstrapping practices falls in line with the findings of Ebben and Johnson (2006) and Vanacker et al. (2011) who place a great importance on the role of owner-related practices (e.g., entrepreneurs' own resources, credit granted by family or friends and factoring businesses, withholding manager's salary) and delaying payments (e.g., delay payment to suppliers) for financerelated bootstrapping.

Table 2. Factor analysis: Rotated factor loadings and main results

\begin{tabular}{|c|c|c|c|c|}
\hline & Financial bootstrapping technique & Factor 1 & Factor 2 & Factor 3 \\
\hline 1 & Use of entrepreneur's credit card for business expense & 0.426 & 0.139 & 0.088 \\
\hline 2 & Commercial loan from family / friends & 0.428 & 0.377 & 0.250 \\
\hline 3 & Withholding managers' salary & 0.889 & -0.143 & 0.025 \\
\hline 4 & Employ relatives or friends at below-market salary & 0.409 & 0.265 & 0.060 \\
\hline 5 & Cease business relations with late payers & 0.465 & 0.302 & 0.158 \\
\hline 6 & Use of interest rate on overdue payments & 0.315 & -0.063 & 0.148 \\
\hline 7 & Delay payment to suppliers & 0.549 & 0.136 & 0.238 \\
\hline 8 & Raise capital from a factoring business & 0.528 & 0.198 & -0.122 \\
\hline 9 & Use methods that speed-up invoicing & 0.149 & 0.506 & 0.102 \\
\hline 10 & Offer same conditions (price, commercial credit, etc.) to all customers & -0.024 & 0.174 & 0.047 \\
\hline 11 & Coordinate purchases (suppliers) with other businesses & 0.103 & 0.493 & 0.182 \\
\hline 12 & Use routines in order to minimize stocks & 0.158 & 0.728 & -0.002 \\
\hline 13 & Use discounts for customers that pay in cash & 0.180 & 0.702 & -0.058 \\
\hline 14 & Choose customers who pay quickly & 0.128 & 0.673 & 0.188 \\
\hline 15 & Borrow equipment from other businesses & 0.068 & 0.196 & 0.772 \\
\hline 16 & Use bartering (instead of buying) for goods and services (inputs) & 0.290 & 0.296 & 0.404 \\
\hline 17 & Lease equipment instead of buying & 0.359 & 0.239 & 0.393 \\
\hline 18 & Share premises / facilities with other businesses & 0.014 & 0.163 & 0.623 \\
\hline \multirow[t]{3}{*}{19} & Share employees with other businesses & 0.242 & -0.079 & 0.831 \\
\hline & Proportion of variance explained & 0.2632 & 0.1097 & 0.1003 \\
\hline & Cronbach's alpha & 0.6295 & 0.6324 & 0.6340 \\
\hline
\end{tabular}


The second latent factor, customer-related and resource optimization, includes six bootstrapping techniques that capture the relationship between the business and its customers. Following the taxonomy proposed by Winborg and Landström (2001), this factor reflects techniques related to the minimization of accounts receivable. In this case the results are consistent with the findings reported by Carter and Van Auken (2005), Ebben and Johnson (2006) and Horváth and Szerb (2018).

Finally, the third factor, identified as 'joint utilization' based on the classification of Winborg and Landström (2001), includes five bootstrapping techniques related to borrowing or sharing resources with other businesses. The results for the third factor reflect the findings by Ebben (2009) as well as Vanacker et al. (2011) and coincide with the importance for SMEs of bootstrapping techniques related to sharing different resources to avoid outside financing.

Looking at the overall use of bootstrapping techniques, our results indicate that Costa Rican SMEs use a diverse set of bootstrapping practices, which can arguably be consequence of their managerial efforts for overcoming financial constraints associated with their liabilities of smallness and newness (Horvath and Szerb, 2018)

The main difference between the results presented in this study and the findings reported by Winborg and Landström (2001) is that owner-related methods and delaying payment techniques are loaded on a single factor, while customer-related techniques and joint utilization methods are loaded on different factors. The former result (owner-related and delaying payment methods included in the same factor) suggests that bootstrapping techniques linked to delayed payments mostly affect owners and

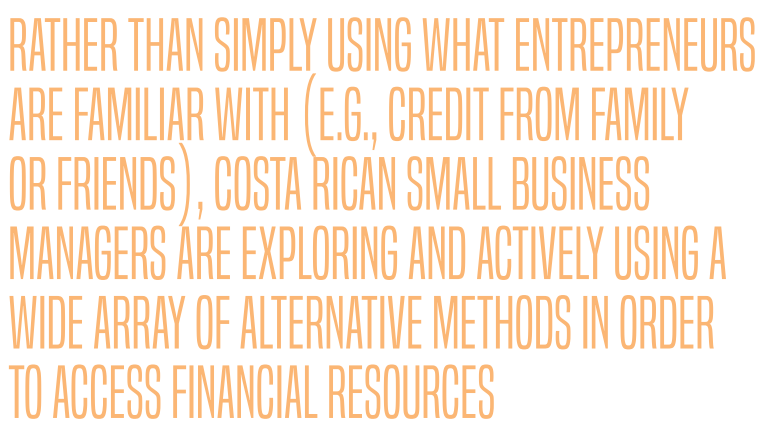

employees with strong ties to owners (this intuition can be verified in Table 1 from a descriptive perspective). In the case of the latter finding, customers and other firms operating in similar sectors are stakeholders with clearly different roles in the business' value chain, which can explain why bootstrapping techniques related to these stakeholders are loaded in different factors.

\section{CONCLUDING REMARKS, IMPLLCATIONS AND FUTURE RESEARCH LNES}

\section{CONCLUSIONS}

Financing business operations is one of the most important decisions that entrepreneurs make, and the credit constraints often faced by SMEs in the early stage of the business increases the relevance of this decision (e.g., Storey, 1994; Davila et al., 2003). In line with this argument, in this study we identified and analyzed the financial bootstrapping techniques used by small businesses in Costa Rica. More concretely, this study presents the results of a survey designed to study how Costa Rican entrepreneurs bootstrap their businesses.

Research rooted in conventional approaches assumes that businesses will raise financial resources in a way consistent with finance theory. However, information asymmetries between suppliers of finance and the business, as well as the costs of debt and equity affect owners' decisions regarding finance strategies (Carter and Van Auken, 2005). Many studies have questioned the applicability of these assumptions to small firms. In this sense, financial bootstrapping techniques are important to SMEs because they constitute a solution to the lack of access to finance via traditional markets (i.e., debt and equity markets) (Ebben, 2009).

The core results of this study emphasize the relevance of bootstrap financing for SMEs. We found that Costa Rican entrepreneurs are actively using a variety of bootstrapping techniques that can be grouped in three categories: a set of techniques related to financial issues, a group of customer-related and resource optimization techniques, and techniques connected to borrowing 
and sharing resources and other assets with other organizations.

This study contributes to the general knowledge of financial bootstrapping techniques by increasing our understanding of the use of bootstrap financing among entrepreneurs located in a developing setting, namely Costa Rican firms. This contribution is valuable since financial bootstrapping is important to SMEs; however, this topic has received little attention in prior studies.

\section{IMPLICATIONS}

The results of this study have important implications for academics, practitioners, and policy makers. Bootstrap techniques represent a potential substitute for traditional outside capital. In this sense, the recommendation for entrepreneurs and SME managers is to recognize and adopt a variety of financial bootstrapping techniques if a business with greater survival and growth potential is the desired objective. Some bootstrapping techniques require planning, while others result from day-to-day business operations. Therefore, reliable and more complete information about all potential sources of capital can help SME managers to develop flexible financial strategies that contribute to business performance. The development of strategies based on bootstrapping techniques is among the benefits of enhanced information availability. Managers and entrepreneurs equipped with reliable businessspecific information will be in a better position for proposing solutions for cash flow problems in the shortand in the long-term (Horváth and Szerb, 2018).

In a related manner, the results of this study can be used by policy makers and support agencies that assist SMEs with financial planning. Policy makers will be well advised to consider the potential benefits of policies that endorse the use of bootstrapping techniques in the long run. This logic suggests the need for rethinking the design of training programs for entrepreneurs (e.g., developed by universities or governmental agencies supporting entrepreneurship). Financial bootstrapping techniques can easily be included in training programs for potential and experienced entrepreneurs.

\section{LIMITATIONS AND FUTURE RESEARCH LINES}

As with any study, the results presented in this work are open to future verification. In this sense, it would be valuable to extend the proposed analysis in various directions. First, the survey data used in this study does not allow to evaluate the relationship between the use of financial bootstrapping techniques and business performance metrics. In this sense, future studies should verify the antecedents and subsequent performance consequences of using different types of bootstrapping techniques. Second, in a closely related manner, future research should evaluate the relationship between local economic conditions (e.g., economic development level) and the adoption of financial strategies based on bootstrapping techniques.

Finally, our data does not permit the direct analysis of the decision-making processes that precede the adoption of bootstrapping methods. Future studies should, for example, evaluate the economic and organizational costs related to the adoption of managerial practices.

Aghion, P. (2017). Entrepreneurship and growth: lessons from an intellectual journey. Small Business Economics, 48(1), 9-24.

Baglin, J. (2014). Improving your exploratory factor analysis for ordinal data: A demonstration using FACTOR. Practical Assessment, Research \& Evaluation, 19(5), 2.

Bhide, A. (1992). Bootstrap finance: The art of start-ups. Harvard Business Review, (November/December), 109-117.

Brush, C. G., Carter, N. M., Gatewood, E. J., Greene, P. G., \& Hart, M. M. (2006). The use of bootstrapping by women entrepreneurs in positioning for growth. Venture Capital, 8(1), 15-31.

Carter, N., Brush, C., Greene, P., Gatewood, E., \& Hart, M. (2003). Women entrepreneurs who break through to equity financing: the influence of human, social and financial capital. Venture Capital, 5(1), 1-28.

Carter, R.B., \& Van Auken, H. (2005). Bootstrap financing and owners' perceptions of their business constraints 
and opportunities. Entrepreneurship \& Regional Development, 17(2), 129-144.

Colton, D., \& Covert, R. (2007). Designing and Constructing Instruments for Social Research and Evaluation. John Wiley \& Sons, San Francisco, CA, USA.

Cooper, A., Gimeno-Gascon, F.J., Woo, C. (1994). Initial human and financial capital as predictors of new venture performance. Journal of Business Venturing, 9, 371-395.

Davila, A., Foster, G., Gupta, M. (2003). Venture capital financing and the growth of start-up firms. Journal of Business Venturing, 18, 689-708.

Ebben, J.J. (2009). Bootstrapping and the financial condition of small firms. International Journal of Entrepreneurial Behavior \& Research, 15(4), 346-363.

Ebben, J.J., \& Johnson, A.C. (2006). Bootstrapping in small firms: An empirical analysis of change over time. Journal of Business Venturing, 21(6), 851-865.

Ebben, J.J., \& Johnson, A.C. (2011). Cash conversion cycle management in small firms: Relationships with liquidity, invested capital, and firm performance. Journal of Small Business \& Entrepreneurship, 24(3), 381-396.

Ekanem, I. (2005). 'Bootstrapping': The investment decision-making process in small firms. British Accounting Review, 37(3), 299-318.

Ferrando, P.J., \& Lorenzo-Seva, U. (2017). Program FACTOR at 10: Origins, development and future directions. Psicothema, 29(2), 236-240.

Freear, J., Sohl, J.E., \& Wetzel, W.E. Jr. (1995). Who bankrolls software entrepreneurs? Paper presented at the Babson College Entrepreneurship Research Conference, London, UK.

Grichnik, D., Brinckmann, J., Singh, L., \& Manigart, S. (2014). Beyond environmental scarcity: Human and social capital as driving forces of bootstrapping activities. Journal of Business Venturing, 29(2), 310-326.

Hayton, J.C., Allen, D.G., \& Scarpello, V. (2004). Factor retention decisions in exploratory factor analysis: A tutorial on parallel analysis. Organizational Research Methods, 7(2), 191-205.

Harrison, R. T., Mason, C. M., \& Girling, P. (2004). Financial bootstrapping and venture development in the software industry. Entrepreneurship \& Regional Development, 16(4), 307-333.

Horváth, K., \& Szerb, L. (2018). Managerial practices and the productivity of knowledge-intensive service businesses: An analysis of digital/IT and cash management practices. Strategic Change, 27(2), 161-172.

Jones, O., \& Jayawarna, D. (2010). Resourcing new businesses: social networks, bootstrapping and firm performance. Venture Capital, 12(2), 127-152.

Lafuente, E., Acs, Z.J., Sanders, M., Szerb, L. (2019). The global technology frontier: productivity growth and the relevance of Kirznerian and Schumpeterian entrepreneurship. Small Business Economics, in press, doi: https://doi.org/10.1007/s11187-019-00140-1

Lafuente, E., Vaillant, Y., \& Serarols, C. (2010). Location decisions of knowledge-based entrepreneurs: why some Catalan KISAs choose to be rural? Technovation, 30(11-12), 590-600.

Nunnally, J.C., \& Bernstein, I.H. (1994). Psychometric Theory. Tthird edition McGraw-Hill, New York.

Patel, P.C., Fiet, J.O., \& Sohl, J.E. (2011). Mitigating the limited scalability of bootstrapping through strategic alliances to enhance new venture growth. International Small Business Journal, 29(5), 421-447.

Storey, D.J. (1994). New firm growth and bank financing. Small Business Economics, 6(2), 139-150.

Van Auken, H. (2005). Differences in the usage of bootstrap financing among technology-based versus nontechnology-based firms. Journal of Small Business Management, 43(1), 93-103.

Vanacker, T., Manigart, S., Meuleman, M., \& Sels, L. (2011). A longitudinal study on the relationship between financial bootstrapping and new venture growth. Entrepreneurship \& Regional Development, 23(9-10), 681-705.

Venkataraman, S. (2003). Creating something new and of enduring value with very limited resources. The Portable MBA, 4th ed. John Wiley \& Sons, New York, NY (pp. 45-163).

Winborg, J. (2009). Use of financial bootstrapping in new businesses: a question of last resort? Venture Capital, 11(1), 71-83.

Winborg, J., \& Landström, H. (2001). Financial bootstrapping in small businesses: Examining small business managers' resource acquisition behaviors. Journal of Business Venturing, 16(3), 235-254. 